\title{
“就是”と “只是”——補足注釈機能について—
}

\section{宇 都 健夫}

(東京大学・院)

提要 本文着眼丁 “就是” 和 “只是” 这两个表达补充注释的词语, 分析 其句法及语义特征, 详论两者的形成过程, 并以此议论为基础来说明两者 之间的差异。“就是” 和 “只是” 两者分别为单音节限定性范围副词 “就”、“只”加上系词 “是” 所形成的双音节副词, 最终获得了表达补充 注释的功能。与 “可是” 等单纯表达逆接的连词不同, 带有补充注释功能 的 “就是”、“只是”, 给句子加上了 “表达出评价” 的特征。特别是 “就 是” 所表达的补充注释, 可以说是给人物做出评价的一种表达方式。虽然 都是表达补充注释, “就是” 和 “只是” 在信息重点置于何处上, 以及两 者出现的句子的特征上有差异。这些差异可以从两者各自的形成过程来给 予合理的解释。

关键词 “就是” “只是” 补充注释功能 主观性评价

1.はじめに

\section{1. 補足注釈の “就是” と “只是”}

現代中国語の “就是” は、様々な機能・用法を持つ語である。その中 で、本稿が特に興味深い用法として注目するのは、以下の例 (1)、(2)のよ うなものである。

（1）你父亲可真是好人哪, 就是不大会做生意, 啊, 不大会做生意。 老舍《二马》"

（お前の親父さんは本当に良い人じゃが、ただ商売が不得手じゃ な。)

(2) 他真心疼你, 就是思想保守一点。马小弥《鼓书艺人》

(あの人は心から君を可愛がっているのだけど、ただ考え方が少 し保守的なんだ。)

これらの文において、“就是”はいずれも、二つの命題を持つ文の後節 に用いられ、前節の内容に対する補足注釈的な内容を表す働きをしてい る。実際の用例を見ると、以下のように文や発話の冒頭で用いられるもの 
もあるが、いずれにしても先行文脈を必要とし、後続する文の冒頭に位置 している。

（3）(又细端详了她一番）真长的好! 就是不大爱说话! 老舎《谁先 到了重庆》

（実にべっぴんだ!ただあまり話をしたがらん！）

本稿では、このような “就是”を「補足注釈の “就是”」と呼ぶ事にす る。

以上に挙げた“就是”と同じょうな用法が、“只是”にも見られる。

(4) 我早就发现了这点, 迨是没想到你会如此糊涂。王海鸰《牵手》 （养はとっくにこの事には気付いていたんだが、ただ君がこれほ ど間抜けだとは思いもよらなかった。）

(5) 老人站了起来, 在小房间踱着圈。件件家具都还是摆在老地方, 只是家具的颜色全都黑了。池莉《细腰》

（老人は立ち上がり、小部屋をぐるりと歩き回った。どの家具も 相変わらず元の場所に置かれていたが、ただ家具の色はどれも

すっかり黒ずんでいた。）

これらの “只是”も、いずれも複文の後節冒頭に用いられ、前節に対す る補足注积を表すものである。本稿はこのような “只是”を「補足注釈の “只是”」と呼ぶ事にする。

\section{2. 問題提起}

“就是”、“只是”による補足注釈は、中国語の複文における接続機能の 一タイプと考えられるものである。複文に関する先行研究には蓄積がある が、管見の限り、補足注积という機能は案外注目されていない。

補足注釈の “就是” と “只是” は、内容的に何らかの対立関係が認めら れる二つの命題を接続するという点で、“可是”、“但是” 等と同じカテゴ リーに属するものである。但し、李庆昌 1954:58-59 や张谊生 2000:156-158 が指摘するように、“就是”、“只是”と “可是”、“但是”とでは、前節に 対する後節の命題内容の性質が異なる て、後節が前節の一部を打ち消し修正するに過ざない事から、前節の意味 が重く、後節の意味が軽いと述べている。この指摘は当を得たものではあ るが、しかし “就是” と “只是”の特徴として充分なものではなく、より 
詳細な考察を必要とする。

次に浮かぶ問題として、補足注釈の “就是”と “只是”の差異がある。 両者は類義語と言うべき関係にあり、一見すると意味的な差異を見出しに くい。第7節で詳論するが、その差異について具体的に論じた先行研究は 少なく、またその議論を検討しても、再者の差異がどのような特徽から生 じるものなのか、充分な解明には至っていない事が分かる。

その差異を論じる際に必要となるのは、それぞれが補足注釈を表す語と なった形成プロセスを考察する事である。補足注釈の “就是” “只是” は、元を辿ればそれぞれ単音節副詞 “就”、“只”に熬辞“是”が後続して 形成されたものである。この事自体は理解に難くないであろうが、しかし それぞれが具体的にどのような過程を経て補足注釈を表すに至ったのかと いう問題は決して自明でなく、考察が必要である。

\section{2. 補足注釈の “就是” の特徵}

\section{1. 補足注釈の “就是”}

本節ではまず、補足注䣋の “就是”の統語的・意味論的特徵を考察する。

第 1 節で見たように、補足注釈の “就是”は、二つの命題内容を関連付 ける機能を持つものである。このような “就是”の存在自体は一見すると 自明のようであるが、既存の工具書や先行研究において、その扱いは必ず しも一致していない。武克忠主编1992:278-279のようにこれを接続詞と 認定しているものもある一方、これを範囲副詞とするものも少なくないの である。吕叔湘主编 1999:319-320 が以下の例 (6)、(7) における “就是”を 一律に副詞として扱い、“确定范围, 排除其他”と説明しているのは、そ の代表的な例である。

(6) 这孩子挺聪明, 就是有点淘气。

(7) 这些课程里边他就是喜欢数学。

例 (7)の “就是” が限定性範囲副詞である事に異論は無い。限定性範囲 副詞とは、何らかの共通性を持つ幾つかの要素からなる集合において、特 定の要素を排他的に限定する機能を担う副詞の事である。例 (7) では “数 学”が限定の対象になっている。一方、例 (6)のような “就是”は、確か に典型的な限定性範囲副詞と明暸には区別しにくいものである゙”。゙が、 
この “就是”は単に “有点淘气”という成分に範囲を限定しているのでは なく、前節の “这孩子挺㖒明”という人物に対する肯定的評価を表す内容 に対して、ただ一つ欠点があるという否定的評価を補足的に後続させる働 きをしている。つまり、文の接繶機能を担っているうえに、話し手の評価 性を表出する働きをしているのである。これらの特徽は、限定性範囲副詞 には見られないものである。そこで本稿は、このような “就是”に補足注 釈という機能を認め、限定性範囲副詞とは異なるものとして扱う ${ }^{4)}$ 。

\section{2. 補足注釈の “就是”を用いた文の特徴}

张谊生 2004b:427 も指摘するように、補足注釈の “就是”は必ず先行文 脈を必要とする。「補足注釈」という機能を考えれば、この点は理解に難 くないであろう。本稿はこの事に加え、補足注釈の “就是” が用いられる 文の特徵を指摘したい。実例を観察してみると、補足注釈の “就是”は人 物や事物の性格・性状、特に人物についてコメントする文に用いられるの が典型的なのである。

(8) 这个女孩子倒是有几分姿色, 就是有点土气。张欣改编《长篇影 视小说 生活秀》

(この娘は器量はまんざらでもないけれど、ただちょっと田舎臭 い。

(9) “你还是个孩子”, 这话不难听, 就是太轻飘了，…… 铁凝《大 浴女》

(「君はやっぱり子供だ。」この言葉は耳障りではないが、ただあ まりに軽率だった。)

“就是”が用いられる文脈は、常にそのようなもののみに限られている わけではなく、例えば以下のように、場面状況の説明のために用いられる 場合もある。ただその場合でも、中心的な話題となっている人物や事物が 特定できるのが一般的だという点は注意してよい。

(10) 然后她就自己介绍说: 我是妇科的, 我姓孙。其实我在食堂里见 过她, 就是不知道她是妇科的, 也不知道她姓孙。王小波《我的 阴阳两界》

（実は私は食堂で彼女を見た事があった。ただ彼女が婦人科の者 だという事は知らなかったし、また孫という姓だという事も知ら 
なかった。)

このような補足注釈の “就是” の文の特徴は、第 2.1 節で述べた “就是” が評価性を伴うという事と直接的に関わるものである。それはまた、補足 注釈の “就是”の形成プロセスとも密接に関わっている。この点について は、第 6 節で改めて詳論する。

\section{3. 補足注釈の “只是” の特徴}

次に、補足注釈の “只是”について考察を加えたい。工具書類を繙く と、各書ともこのような“只是”を接続詞と認定している。吕叔湘主编 1999:680は例 (11) を挙げ、“表示轻微的转折, 意思重在前一小句中, 后一 小句补充修正上文的意思”という説明を加えている。

(11) 小赵各方面都很好, 只是身体差一些。

吕氏の説明に即してこの例を具体的に見ると、前節で “小赵”という人 物が全般的に優れていると述べた後、後節で体が些か弱いという欠点を補 足的に付け加えている。

一方、“只是”は以下の二例のように、限定性範囲副詞としても用いら れる。限定性範囲副詞の定義は“就是”と同様である。例 (12)、(13)で は、主語“她”の受ける苦痛、“卓雄洲”の動作行為という範囲が設定さ れており、“只是”はそれぞれ波線部の体詞性成分“人家的侮辱”および 述詞性成分 “叹息了一声”を限定の対象としている。

(12) 她什么苦都能吃, 只是不能受人家的侮尉。老舍《四世同堂》

（彼女はどんな苦痛も耐えられたが、他人からの侮辱だけは受け 入れられなかった。)

(13) 卓雄洲没有说话, 只是叹息了一声。张欣改编《生活秀》

（卓雄洲は何も言わず、一声だけため息をついた。）

“就是”に比へ、“只是”における限定性範囲副詞と補足注积との差異は 比較的明暸であると言える。この事は補足注釈の “只是”が用いられる文 の特性に関係していると考えられる。第 2.2 節において、補足注釈の “就 是”は人物や事物の性格や性状について述べる際に用いられる事が多い事 を指摘した。この傾向は、補足注釈の “只是”には見られない。補足注釈 の “只是” は上揭例 (11)のように人物・事物について素描する文で用い 
られる事もないわけではないが、それは決して典型的な使用ではなく、む しろ例 (14)のように一般的な状況説明に至るまで、広汎にわたって用い られるのである。

(14) 你要这么认为也可以, 只是戒毒所是要收费的, 价格还不低。张 欣改编《生活秀》

（君がそう思うのは勝手だけど、ただ中毒患者の治療所は有料 で、値段だって安くない。)

総じて、補足注釈の “只是”は “就是”よりも使用範囲が広く、接続詞 としての地位を確立していると言える。

\section{4. 補足注釈の “只是” の形成プロセス}

第 3節までに見たように、“就是”と“只是”はともに補足注釈の機能 を持つ。本稿では以下、ではそもそも“就是”と“只是”が補足注釈を表 せるのは一体何故なのか、という問題を考えたい。第 1 節で述べたよう に、そのためには、それぞれの形成プロセスの考察が必要である。本節で はまず、先行研究を手掛かりに、“只是”の形成プロセスを検討する。

議論の出発点として、“是”のムード特性の解明の手掛かりとして副詞 “只”が慗辞 “是”を伴って副詞“只是”となる動機を考察した大河内 1975:31-35 の議論を取り上げる。大河内氏はまず、副詞“只”が単独で動 詞や形容詞の前につく場合、一般的傾向としてその後に数量詞を含んでい る事が多い事を指摘し、それらの例について「この種の “只”は動作を限 定しているというより、その述部のなかに含まれる数量を限定している」 と述べる゙。

(15)我的软件就有这么简约, 别人编十行, 我只用一行。王小波 《革命时期的爱情》

（他の人が十行編集するのに、私は一行しか使わなかった。）

(16) 就单说三条大活骆驼, 也不能, 绝不能, 唄值三十五块大洋! 老 舍《骆驼祥子》

（大型の活きた駱駝が三匹だけにしたって、まさかそんな筈が無 い、たった銀貨 35 元にしかならないなんて1)

大河内氏は “只” の機能を「数量限定」と述べるにとどまるが、より重 
要なのは、“只”の意味指向が「少」という点にある事である”。張建華 1998:98-99、李貞愛 2002:185-186 が指摘するように、“只”はとりたてる 対象が何らかの基準に照らして少数である事を表す語である。例えば例 (16)では、“三十五块大洋”は、通念的には必ずしも少額とは限らないで あろうが、この文では話し手にはもっと高額であって然るべきだという思 虑があり、この金額を予想外の少額と捉えているのである。

大河内 1975 は続けて、“只”に対して“只是”は直後の動作を問題にす るものが多く、それらの“只是”は “只”に置き換えられないと述べる。 これはつまり、“只”は本来的にモーダルな性質を持つ要素である“是” と結合して “只是”となることによって、はじめて事柄をとりたてる作用 を持つという事にほかならない”。

(17)他并不后悔, 只是怕, 怕那个无处无时不紧跟着他的鬼。老舍 《骆驼祥子》

（彼は決して後悔してはいなかった。ただ怖かったのである。あ のいつでもどこでも彼にぴったりと付きまとう亡霊が。）

(18) 常常有人说我厉害, 其实我并不厉害; 我只是刚正。老舍《残 雾》

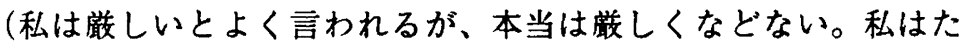
だ一本気なだけなのだ。）

大河内 1975 はこのことを一般化し、“只是”は話し手の主張に積極的に 関与するもの、“只”は命題内容そのものであると述べ、その一つの体現 として、“这些只是表明经济关系的要求而已”（大河内 1975）のように、 モーダルな表現である文末の “罢了”、“而已”と関連するのは“只”より “只是”の方が普通である事を指摘している。“罢了”と“而已”はいず れも、当該の動作行為や状態が話し手にとってさほど重要性を持たないも のであるという話し手の認識を示す語である。上揭の例 (17)、(18)は “罢 了”、“而已”は用いていないが、先行する節とのコントラストによって、 “怕”、“刚正”の重要度が相対的に軽いものであると捉えられている事が 読み取れる。この事から、“只是” は限定する動作行為・状態の重要度が 話し手にとって軽いものである事を含意すると言える。つまり、“只”が 事物の数量が「少」である事を指向するのに対し、“只是”は動作行為・ 
状態の重要度が「軽」である事を指向するのである。また、後述する “就 是”の特徽との差異を視野に入れ、“只是”は上揭例 (12)のように体詞性 成分を限定する事はあまりなく、多くは動作行為そのものの限定に用いら れるという事も、ここで指摘しておく。

大河内 1975 は、“是”のムード特性を考察するという目的から、“只 是”の考察から“副詞＋是”が一般に持つムード性へ論点を移し、単音節 副詞が “是”を伴う事によって文頭に位置し、結果的に接続詞へと近付い てゆくプロセスについて述べている。本稿では大河内氏の議論を承け、 “只是” が副詞から接続詞へと文法化するプロセスを実例に沿って追究し てゆく"。以下の各文を比較されたい。

(19) 她没有再纠缠他, 只是不断观察他。铁凝《玫瑰门》

（彼女はもう彼を邪魔せず、ただじっと彼を観察していた。）

(20) 脸上还没有什么下不去的地方, 只是笑容太过火。老舍《二马》

（顔には面子が立たないような所は無かったが、ただ笑い方が度 を超していた。）

(21)我和白大省看《卖花姑娘》时也哭了, 只是我不如她器得那么专 注。铁凝《永远有多远》

（私と白大省は「花売りの少奵を見たときも泣いた。ただ私は 彼女のように一心不乱に泣くほどではなかっだ）

例 (19)の “只是” は、統語的位置としては副詞とも接続詞とも決めが たい。しかしその意味機能を見ると、主語 “她”の取った動作行為を“不 断观察他”に限定し、他者即ちその对立項である “再纠缠他” の存在を否 定していることから、限定性範囲副詞の域を出ていないと見られる。それ に対し、例 (20) と (21) の “只是” は、節の冒頭という、接続詞と同じ統 語的位置に置かれている。例 (20)の “只是”は、前節において設定され る範囲 “脸” の中で問題は無いと述べておきながら、後節ではそれに反し て“笑容太过火”という久点が一つだけ見つかると補足的に指摘している のである。この “只是”は限定を表すものではあるが、前節と後節との内 容を関連付けているという点で、意味的にも接続詞に近く、粉じて副詞と 接続詞の境界に位置するものと言って良い。更に例 (21) では、“只是”は 意味的に特定の範囲における限定を表しているというょり、むしろ前節で 
述べられている状況全体に対して情報を補足しているものと見るのが妥当 である。ここに至って、補足注粕の接続詞へという機能拡張が実現してい ると考えられる。

以上、本節では、“只是”の副詞から接続詞への拡張過程を説明した。 本節の議論は以下の表 1 のようにまとめられる。

表 1 限定性篹囲剧詞 “只” から補足注彩の接続詞 “只是” への拡張過程

(1)事物の少数限定を指向する範囲副詞 “只” と繁辞 “是” が結合

$\rightarrow$ (2)文中の副詞 “只是”が成立、動作行為の限定を指向

$\rightarrow$ (3)副詞 “只是” か節冒頭（主語の前）に位置し、デキコトの限定を指向

$\rightarrow$ (4)補足注积の接続詞 “只是”が定着

\section{5. 補足注釈の “就是” の形成プロセス}

\section{1. 先行研究}

本節では、第 4 節の “只是” の議論を踏まえ、補足注釈の “就是” の形 成プロセスを考察する。この問題に関する先行研究として、通時的観点か ら補足注釈の “就是” の形成過程を考察した张谊生 2004b:434-437 の議論 が挙げられる。张谊生 2004b は例 (22)など幾つかの例を挙げながら、以 下のような議論を展開している。

「先行文脈に説明を加える場合、“就是 X”の形式を用いて例外を挙げる 時、その目的は明らかに前節の命題内容を肯定することではなく、それに 更に補足・修正を加えることになる。そこで、“就是 X”と先行文脈との 間に転折の関保が派生する。話し手の本来的な意図は例外を示すだけなの であるが、その例外は全体と意味内容上正反対のものであるので、談話全 体の文脈において転折の意味を「含意（衍推 (entail))」する。注目すべき は、転折の “就是” が元来、一つの複文ではなく一連の文（一个句组）に おいて用いられていた事で、話し手自身は “就是”に転折の機能があると は意識しておらず、転折は一種の「再分析（重新分析 (reanalysis))」の結 果にすぎないのである。」

(22) 莫稽见玉奴才貌, 喜出望外, 不费一钱, 白白的得了个美妻, 又且 丰衣足食, 事事称怀。就是朋友辈中, 晓得莫稽贫苦, 无不相凉, 
到也没人去笑他。

魏同賢主編〈馮夢龍全集〉〈古今小說〉下（上海古籍出版社, 1993, p1060)

（莫䄸は玉奴を見ると、思い掛けず大喜びし、一銭も費やさずに ただで美しい妻を手に入れ、更に衣食も満ち足りて、願ったり 叶ったりであった。友人親類達は莫稭が貧しい事を知っていたの で、同情しない者はなく、彼を笑いものにする者もなかった。）

张谊生 2004b の議論は、補足注釈の “就是” は本来一つの複文における 接続詞としてではなく、例 (22) のように複数の文のうちの後方の文の冒 頭で用いられていたもので、複文の接続機能は再分析の結果に過ぎない事 を述べたものである。この議論は的を射たものであり、参照に資する。だ が、“就是” が例外の提示という機能を有している事を前提としている点 に問題がある。というのも、そもそも“就是”によって例外の提示が可能 になるのはなぜなのか、という点が説明されていないのである。そこで本 稿では、その点をも含めた全体的なメカニズムの解明を目指し、限定性範 囲副詞 “就” が “是”を伴って “就是”となり、範囲限定から補足注釈を 表すに至るまでのプロセスを具体的に考察してゆく。考察の手順は基本的 に第 4 節の議論に沿うものであるが、“就”、“就是”の意味特徴は、“只”、 “只是”のそれと全く同一ではない。本稿は、その相違点にも留意しなが ら考察を進める。

\section{2. 補足注釈の “就是” の形成プロセス}

ではまず、“就”が体詞性成分をとりたてる場合を見てみよう。第 4 節 で述べたように、“只”は数量が「少」である事を指向する副詞である。 それに対して、“就”の範囲限定においては、井田 2003:194 が指摘するよ うに、数量の限定は基本的な意味ではなく、むしろ体詞性成分そのものの 限定が基本的意味だと考えられる”。以下の例 (23)、(24)は、対比項の明 示の有無という問題はあるものの、いずれも “就”が後続する体詞性成分 を限定的にとりたて、それ以外の対比項を排除するという機能を担ってい る ${ }^{10)}$ 。例 (23)のように数量表現が後続する場合でも、とりたてているのは あくまで“咱们两个人”という体詞であるという点には、特に留意が必要 である。 
(23)这儿就咱们两个人。王小波《革命时期的爱情》

(ここは俺達二人きりだ。)

(24) 周朴园（沉重地）萍儿, 你原谅我。我一生憱做错了这一件事。

曹禹《雷雨》

（わしは生涯でただ一つ、こんな過ちを犯してしまった。）

これらの例においては、“就”を“就是”に置き換えても、文意に変わ りは無い。つまり “就是”にも体詞性成分を排他的に限定する機能が保た れているわけである。以下の例 (25) の “就是”は限定性範囲副詞の例で あり、主語 “他”が行った行為 “骂”の対象に該当する人物が “你”ただ 一人に限られる、という事を示している。

(25) 他还敢损你、骂你, 就是骂你不骂你们家, 免得家里人来找。

王小波《绿毛水怪》

（あいつはなお君を貶め、罵ろうとしているんだな。君だけを 䍖って家族を䍖らないで、家族が訪ねて来ないようにしているん だ。)

以上はいずれも体詞性成分の限定で、“就”と“就是”がともに使用可 能なケースであった。それに対して、以下のように動作行為そのものを直 接作用域とするならば、通常 “就是”を用いなければならず、“就”単独 では用いる事ができない。

(26) 她们从早到晚轮流问, 不打她不骂她就是/*就问。铁凝《玫瑰门》

（彼女達は朝から晚まで入れ代り立ち代り質問した。たたいたり

甾ったりはせず、ただひたすら訊ねるのだった。）

次の例 (27)における “就是” は、主語 “我们” の行った行為が “一起聊 天”のみに限定される事を表しているが、前節において “什么都没干”と範 囲を明示している事から、範囲限定と補足注釈を兼ねたものと見られる。

(27)我们估么都没干, 就是一起聊天来着。王朔《给我顶住》

（我々は何もしていない、ただ一緒に雑談していたんだ。）

それに対し、次の例では補足注釈を表す “就是”へと完全に移行してい る。

(28) 我在这边一切都好, 不必挂念, 産是有时会想你们。张欣改编 《生活秀》 
（私はこちらでうまくやっていますから、心配には及びません が、ただ時々あなたたちが恋しくなります。）

この例においては、“就是”に“有时会想你们”という話し手の行為が 後続している点では例 (27) と同様であるが、これを含む範囲は明確でな く、「話し手 “我”の状況」とでも言うべき抽象的なものになってしまっ ている。したがって、“就是”は “有时会想你们”を排他的に限定してい ると解釈するよりも、前節で述べた内容に対する補足注釈を表していると 考えるのが妥当である。以上の例 (28) と同様に説明できる例として、例 (29) を挙げる。

(29)张驰一看, 赶紧过来帮九妹一块铺床, 说: “你也够累的了, 我来 ……”九妹坐下来採脚, 说 : “我倒不累, 就是高跟鞋把脚夹得好 痛……”张欣改编《生活秀》

(「君も随分疲れただろう、僕がやるよ……九妹は座って足を 揉みながら言った、「疲れてはいないわ、ただハイヒールがきつ くて痛いの…」」)

この例の “九妹” の発話は、前節で相手の “你也够累的了”という発話 を否定し、後節でそれに補足的な説明を加えたもものである。“就是”に主 述構造が後続しているが、“就是”の作用域は直後の体詞性成分 “高跟 鞋”のみにあるのではなく、“高跟鞋把脚夹得好痛”という構造全体にあ る。この文においては、特定の範囲の要素を “就是”が限定しているとは 解釈しにくい。前節と後節に共通する範囲を強いて挙げるとすれば、話し 手 “我”の身体の状況とでも言うべきものになろう。

以上本節では、“就是” が限定性範囲副詞から接続詞へと拡張するプロセ スを明らかにした。本節の議論は以下の表 2 のようにまとめる事ができる。

表 2 限定性範囲副詞 “就” から補足注釈の “就是” への拡張過程

(1)体詞性成分を限定する籍囲副詞 “就” と繁辞 “是”が結合 $\rightarrow$ (2)文中の副詞 “就是” が成立、体詞性成分の限定を指向

（3)文中の副詞 “就是” が動作行為の限定を指向

（4)副詞 “就是” が節冒頭（主語の前）に位置し、デキコトの限定を指向 $\rightarrow$ (5)補足注釈の “就是”が定着 
6. 補足注釈の “就是”、“只是”による主篗的評価の表出

\section{1. 補足注釈の “就是”、“只是”による主観的評価}

本節では、補足注釈の “就是”と“只是”が用いられる際に生じる主観 的評価をめぐる問題を考える。議論の端楮として、张谊生 2004b:427-428 の指摘を取り上げよう。张氏は、“就是”による “转折”を、例 (30)のよ うに語用論的に話し手にとって残念・遗憾であるという副次的な語気を伴 う場合と、そのような語気を伴わず前節の補足・追加に過ぎない場合とに 分け、そのような語気が生じる事の原因を、“就是”によって表出される

「例外」が一般に話し手あるいはその関係者にとって不本意なものである ためだと説明する。

(30)老寿的老婆是个苦死累死不讨饶的硬女人, 就是爱唠叨几句。

茹志鹃《尊辑错了的故事》(茹志鹃《草原上的小路》, 百花文艺出 版社, 1982, p64)

（老寿の妻はどんな苦労にも音をあげない硬骨の女だったが、た だ少し愚痴っほかった。）

補足注釈の “就是”による発話に残念・遺憾の語気を伴う場合があると いう张谊生 2004b の指摘は、確かに留意に值するものである。更に観察を 進めると、张氏の言及していない言語事実が幾つか見出される。

第一に、残念・遺憾の語気を伴うという特徵は、“就是”ほど顕著では ないものの、補足注釈の “只是”にも当てはまる。即ち、これは補足注釈 という機能が持つ特徵の一つなのである"1)。とりわけ、人物評価をする際 に “就是”ゃ “只是”を用いて欠点を婉曲に指摘するのは、一種の待遇表 現と考えてよい"2)

第二に、以下のように、補足注釈の “就是” の前後に話し手の心的態度 を表す “可”や“可惜”といった語が用いられる事は、それを亭付けるも のである ${ }^{13)}$ 。

(31) 她喜欢读书, 人也聪明, 可就是有点儿乘僻, 一天到晚, 一句话 也不说，不知道的人还以为她是个哑巴。杨沫《青春之歌》 （彼女は勉強が好きで、頭も良いけれど、ただちょっとつむじ曲 がりだ。)

(32)您看看志芳的手吧, 全扎坏了! 鱼、虾, 是真好吃啊, 可惜就是 


\section{爱扎人! 老舍《女店员》}

（魚と蝦は本当においしいわ、ただあいにくよくとげが刺さるの よね!)

以上のように、张谊生 2004b の指摘は基本的に妥当なものと言える。だ が、問題点も無いわけではない。第一に、张氏は残念・遺憾の語気が生ず る場合と生じない場合とに二分しているが、その判別基準が不明である。 第二に、上述の通り张氏の説明のポイントは “就是”が例外を表すという 点にあるのだが、それだけではこの現象の説明に充分とは言えない。以下 の例 (33)に見るように、限定性範囲副詞“就是”を用いた場合には、他 に長所は無いが、唯一良い点が有る、という文を形成する事が可能だから である。

(33)毕科长 局长信任兄弟, 兄弟自信还会当差, 还有个忠心; 别的 好处没有, 就是忠于局长。老舍《残票》

(畢科長 局長は弟殿を信頼しているし、弟殿も役人だって勤ま るし、それに忠心もあると自負している。他に長所は無いが、た た局長に忠実なのだ。）

それに对して、興味深いことに、補足注釈の “就是”が用いられる場合 は、必ず前節が話し手にとって好ましいと思われる内容、後節が逆に好ま しくないと思われる内容になる。言い換えれば、必ず前節がプラス評価、 後節がマイナス評価になるわけである。

(34)沈维义 他联明, 又肯用功, 就是心里老不开展! 老舍《全家 福》

（沈維義 彼は賢くて、それに一生㥿命だけれど、ただいつも暗 いんだ!)

論理的には、例 (35)、(36)のように、前節がマイナス評価で後節がプラ ス評価の文があっても良いはずである。ところが実際には、これらの文は 成立しない。

(35) ${ }^{*}$ 他心里老不开展, 就是聪明, 又肯用功!

(36) ${ }^{*}$ 他不聪明, 又不肯用功, 就是心里老开展!

この点は “只是”でも同様である。

$(37){ }^{*}$ 他心里老不开展, 只是聪明, 又肯用功! 
なお、“可是”等による単純な逆接の文においては、必ずしも上記のよ うな制約は無い。

(38) 她长得不美, 可是眉眼很媚; 她的眉眼一天到晚在脸上乱跑。

老舍《四世同堂》

（彼女は美人ではなかったが、顔立ちは麗しかった。）

この事から、“可是”等による逆接と “就是”、“只是”による補足注釈 とは性質的に異なる事が見て取れる。即ち、両者はともに反順接の接続機 能に属するものではあるが、主観的評価の表出の有無という点で差異が見 られるのである。

\section{2. 主観的評価表出の要因}

では、補足注釈の “就是”、“只是”を用いる事による主観的な評価は、 一体どこから来るのであろうか。

主観的評価の表出という事で思い浮かぶのが、形容詞に対する “有点 儿”という語在の在である。周知の通り、“有点儿”はいわゆる貶義の 形容詞の前方にのみ用いられる。逆に言えば、貶義の表現にのみ“有点 儿”という語彙が用意されているわけである。これは、望ましくない事柄 は小さく言いたいという普遍的な婉曲意識の表れであると言える。補足注 釈の “就是”、“只是”が専ら望ましくない事柄に用いられるという事実 も、これと同様に考える事ができる。望ましくない事柄は、直截的に述べ るよりも補足注釈として控えめに、小さく述べるほうが好ましい。“就 是”、“只是”は、本来は限定性範囲副詞なのであった。数ある選択肢の中 から「ただこれだけ」「ただーつだけ」と範囲を限定するのは、まさにそ のような「小さく言う」事にほかならない。限定性範囲副詞の “就是”、 “只是”が補足注釈の接続語に拡張する動機はまさにここにあると考えら れる。

以上の議論を踏まえて、ここで反順接表現における補足注釈の位置付け を確認しておきたい。中国語の反順接表現には、少なくとも二つのタイプ がある。一つは “可是”、“但是” 等の「逆接」、即ち前節の内容に相反す る対立的な命題内容を後節に提示し、真っ向から「逆説」する夕イプ、い ま一つは “就是”、“只是” の補足注釈、即ち前節の内容に対する補足とし て控えめに反順接的な内容を付け加えるものである。補足注釈は、反順接 
の機能としては「逆接」ほど典型的ではないが、話し手の主観的評価が表 出されるという特徽が有り、ここに、控えめな反順接接続という、待遇性 に富む複文の一つのタイプが成立している。

\section{7. 補足注釈の “就是” と “只是” の差異}

本節では、補足注䣋の “就是” と “只是” の差異について論じる。第 4 節、第 5 節において、両者は共に限定性範囲副詞から機能を拡張して成立 したものであり、そのプロセスには共通の基盤が認められることを明らか にした。意味的に見ても、両者は類義的であると言ってよく、実際いずれ を用いても意味的に明確な差異が見られない場合が少なくない。邢福义 2001:299-300は例 (39) を挙げ、この文では “就是”と“只是”のいずれ を用いても、意味上基本的に異なる点は無いと述べる。

(39) 这孩子不错, 就是/圆是不怎么聪明。

(この子供は悪くないが、ただあまり賢くない。）

但し刑福义 2001 は同時に、“就是” と “只是” とを比較すると、“就 是”は軽い補足注釈を表すと同時に、後節に述べられている事柄、即ち “不怎么聪明”という欠点が中心的問題であることを幾らか強調するのだ という考察も加えている。邢氏はまた、同様の理由から、例 (40)では “就是”を “只是 (……罢了)” とするとどうしても原義に合致しなくな ると述べる。

(40)老贾坐在炕沿上，拍拍张老五的肩, 说: “叫她说两句怕什么? 有 缺点还能怕人说。你这人, 什么都好, 就是脾气赖坏了事, 不是人 家妇女们批评你封建, 看, 你对自己的老婆这是什么态度! ”西 戎《纠纷》 (《西戎代表作》, 黄河文艺出版社, 1987, p97)

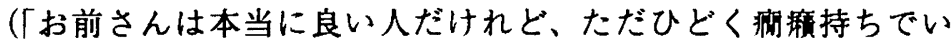
けない。よその奥さん達がお前さんを封建的だと批判している通 りじゃないか、ほら、自分の奥さんに向かってその態度は何 だ!」)

邢福义 2001 の指摘は、“就是”を用いた場合は文内容の重点が後節に置 かれ、逆に “只是”を用いた場合は文内容の重点が前節に置かれる事を 言ったものと解积できる。例 (40)は、妻を叱責した “张老五”を “老贾” 
が諌めている場面である。一連の文脈における “老贾”の発話意図は、聞 き手 “张老五”が妻に対して取った態度を諌める事にあり、下線部におけ る “就是”はひどく怒りっぽいという相手の欠点が看過できないものであ る事を言明する役割を果たしている。ここで “只是”を用いると、話し手 の主眼は前節、つまり相手は本当に良い人だという点に置かれ、後節の欠 点はそれをわずかに損なう程度のものだというニュアンスになる。する と、相手の封建性や妻に対する態度を祭める発話意図と整合しないのであ る。以上の検証から、“就是”による補足注釈は「後節重点型」、“只是” による補足注釈は「前節重点型」と呼ぶ事ができる。

しかし、上揭邢福义 2001 の説明が充分に適用できないようなケースも 存在する。それは、例 (40) とは逆に、補足注釈の “只是”を “就是”に 置き換えにくい場合である。

(41)你不算厉害, 你其实挺温柔, 只是/ ? 就是我太自私。王朔《过 把瘾就死》

（お前は厳しくなんかない、実の所お前は大人しい、ただ俺が勝 手過ぎるんだ。)

(42)“他很好。”陈毅说：“仗打得很勇敢, 老毛病改掉不少, 上个月入 的党, 今天早上提升营长了。只是/? 就是他眼下的处境很困 难。”邓友梅《我们的军长》

(「戦いぶりも勇敢だし、悪い癖も相当良くなっているし、先月 入党して、今朝には大隊長に昇格したし。ただ彼の今の境遇は相 当厄介ですがね。」)

删福义 2001 の説明、即ち情報の重点という観点からすれば、これらの 例において、“就是”によって後節に重点を置く事も可能なように思われ る。だがインフォーマントによると、“就是”を用いると文が不自然に なってしまうというのである ${ }^{14)}$ 。

本稿はこの事について、“就是”と “只是”の本質的な意味に即した説 明を試みたい。上揭例 (41)、(42)の共通点として見出せるのは、いずれも 当該文の前節の主語あるいは主題そのものについて補足注釈を加えている のではなく、それ自身には何ら問題は無いが、外在的に何らかの障害が発 生している事を後節で補足的に述べている、という事である。統語的に見 
ても、これらの文では前後の節で主語もしくは主題が異なっている ${ }^{15)}$ 。補 足注釈の “就是” は、このような文には用いられにくい。本稿は、このよ うな差異は副詞 “就是” と “只是” の限定機能の違いに起因するものと考 える。第 5 節で検証したように、箅囲副詞 “就” は排他的限定、言い換え れば唯一性を表すものであり、それが “就是”にも引き継がれているので あった。“就是”によって何らかの人物や事物が唯一性を持っていると述 べるためには、それに対応する要素の集合範囲が定まっている必要があ る。例 (41)、(42)では、範囲が漠然とし過ぎていて、一体どのような事柄 を“就是”によって唯一性を持つものとして特化させるべきなのか、特定 できないのである。逆に、人物や事物の性格や性状が問題となっており、 前後節で主語もしくは主題が一貫している場合には、範囲が極めて明確で ある。それが補足注釈の “就是” が用いられる典型となるのも、領ける事 であろう。

一方、第 4 節で検証したように、“只是”は数量の少なさを指向する “只”に由来し、範囲副詞として働く場合、当該の動作行為の重要度が 「軽」であるという話し手の認識を内包するのであった。“只是”は動作 行為、更には命題そのものに限定を加えてゆく事ができるが、それにつれ て同類要素の存在、及び範囲の指定という点への関心が薄れてゆく。そし て補足注釈として機能する場合、先行文脈に何らかの状況が設定されさえ すればよいという事になってゆくのである。この場合には、“就是”に見 られたような、前後節の主語や主題の一貫性という統語的な制約も生じな い。総じて、補足注䣋の “只是” のほうが “就是” りりも使用轮囲が広 く、従って補足注积の “就是” は多くの場合 “只是”に置き換えられる が、その逆は制限がより笅しいという事が指摘できる。

\section{8. まとめ}

本稿では、補足注釈の “就是” と “只是” という二つの語に着目し、そ れぞれの統語的・意味的特徴を明らかにするとともに、それぞれの形成プ ロセスを詳論し、更にその議論を基に両者の差異を明らかにした。補足注 釈とは、複文前節の内容の全面的な肯定を保留し、後節において反順接的 な内容を婉曲に提示する機能である。補足注积の “就是” と “只是” は、 
“可是”、“但是”等の逆接とは異なる、独自の特徵を持つものである。両 者の形成過程を考察すると、細部に相違はあるものの、いずれも単音節の 限定性範囲副詞 “就”、“只”に餐辞 “是”が附加し、二音節の限定性範囲 副詞を経て、最終的に補足注釈を表す機能を獲得したものである事が分か る。このようにして形成された補足注釈の文には、限定性範囲副詞の文に は見られない特徽が生じる。とりわけ“就是”を用いた文は、人物・事物 の特性について後節で唯一の欠点を婉曲に付け加えるケースが典型的であ ク、それはおのずと一種の待遇表現と言うべきものとなる。これは普遍的 に見られる待遇意識の体現の一つであると考えられる。

“就是”と“只是”は同じ補足注釈と言いながら、“只是”は前節に、 “就是”は後節に情報の重点が置かれる点、また、“只是”が広く状況説 明に用いられるのに対し、“就是”は上記のような人物・事物の特性の描 写に用いられる点に、差異が見られる。両者に見られるこれらの差異は、 それぞれの形成過程に基づいて説明する事ができるものである。

\section{<注〉}

1）本稿で挙げる例文のうち、下線を引いたものについては、その部分のみを訳出す る。

2）本稿では、これらの接祱表現を包括して「反順接」と呼び、“可是”等を「逆接」、 “就是”と “只是”を「補足注採」と呼ひ、、再タイブを明確に区別する。第 6.2 節参 照。

3）実例を観察しても、次のようにいずれとも判別しがたい例が少なくないのは事実で ある。

(43) 她对五岁的她说: “个儿倒是不矮, 就是瘦。”铁凝《玫瑰门》

(「身長は案外低くないんだけと、、ただ瘦せてるのよね。」)

4）補足注粕の “就是”は、典型的な箷囲副詞とは明らかに異なるものの、後述する補 足注釈の “只是” とは異なり、接続詞と認定する充分な根拠も提示しがたい。そこで 本稿では、巣密な品詞認定の検討は避け、接続詞的な性啠を持つとの認識を示すにと どめておきたい。

5）以下の例と訳文は、本稿が新たに提示するものである。但し、例(16)は張建華 1998:99、130でも引用されている。

6）「数量限定」というだけでは意味指向は「少」とは限らない。李貞愛 2002:184-188 は、副詞 “净”が複数を限定し、意味指向は「多」である事を指摘している。 
7）副詞に付加する形態素 “是”がムード性を持つという点に関しては、近年、张谊生 2004a、董秀芳 2004 によっても詳しく論じられている。

8）なお、以下の考察に当たっては、日本語の副詞「ただ」が「限定副詞」から接続詞 へと変退する過程を論じた工藤 1982:983-985が参考になる。

9）“就”が数量詞を伴う場合、意味指向は「少」とは限らない。以下の二例とその説 明は侯学超编 1998:346-347に挙げられているものだが、数量の指向の対比が明確に見 て取れる。

（44）你一次就买二百斤大白菜, 吃得了吗?（表示说话人认为数量大）

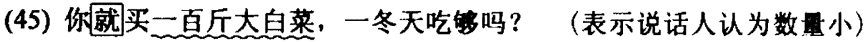

10）このような“就”の機能を、井田 2003 は「限定取り立て」と呼んでいる。

11）類似した現象か、日本語の被文の後節冒頭に用いられる「たた」にも見られ（川 越 2003:92-94)、参考に值する。川越2003は、そのような「ただを用いた文では、 前節の内容を一応「好ましい」こととして述べてから後節で逆の「好ましくない」評 価の内容を補足する傾向が顥著である事を指摘し、そのような前後節の評価のギャッ ブは話し手の不本意さを暗示する、と述べている。但し、川越氏は前後両節の評価性 が逆になっている文も挙げ、前節が「好ましい」事柄であるのは絶対条件ではなく、 ただそうなる場合がわれわれの言語行動の性質上多いというだけだろう、との見解も 示している。この点は、本稿の補足注釈の “就是”、“只是”に対する見解とは異な る。

12）沈家椬 1999:125-126は、言語を用いた評価、とりわけ人物の社会的行為の評価に 当たっては、久点は婉曲に、長所は存分に述べようとする「待遇原則（礼貌原则）」 がしばしば適用される事を指摘している。補足注釈の “就是”、“只是”による主観的 評価の表出は、まさしくこの原則に符合するものである。

13）補足注釈の“只是”は、“可”ゃ“可惜”と共起寸る事はあまりないようだ。これ は “就是”と“只是”とでは前後の節に置かれる重点が異なる事の反映であると考え られる。

14）これらの例の容認度はインフォーマントによって程度の差が有るが、不自然とす るインフォーマントがいるのは確かである。

15）各文の主語・主題を波線で示す。なお、例 (42) で “就是”を用いにくいとするイ ンフォーマントによれば、“就是”の直後の“他”を省略しても、不自然さは変わら ないという。

\section{<参照文献>}

井田みずほ 2003.「副詞 “才”の取り立て機能について—“就”との比較から」、「中 国語学」第 250 号：190-210 頁。日本中国語学会。 
川越菜穂子 2003.「補足の接続詞「たた」「ただしについて—〈閐き手配虑〉を使用 条件にした分析一」、帝场山学院大学人間文化研究年報」第 5 号 : 82-101 頁。帝塚山学院大学。

工藤浩 1982.「叙法副詞の意味と機能——その記述方法を求めて」, 「国立国語研究所報 告 71 研究報告集 3」969-986 頁。国立国語研究所。

大河内康害 1975.「“是”のムード特性」「中国語の諸相」27-52 頁。白帝社, 1997 年。 本貞受 2002.「副詞“净”について」、「中国語学」第 249 号：181-195 頁。日本中国語学 会。

張建華 1998.「日中語の限定表現の研究——だけ」「ばかり」「しか」と“只”“净”を 中心に一」」絢文社。

董秀芳 2004.「“是”的进一步语法化：由虚词到词内成分」,「当代语言学】第 1 期 : 35-44 页。

侯学超编 1998.「现代汉语虚词词典」。北京大学出版社。

李庆昌 1954.「谈谈两种转折复句的区别」、「语文学习」10月号：58-60 頁。中国青年出 版社。

吕叔湘主编 1999.「现代汉语八百词增订本」。商务印书馆。

沈家椬 1999. 「肯定与否定对立的消失」, 「不对称和标记论」115-146页。江西教育出版 社。

武克忠主编 1992.【现代汉语常用虚词词典」。浙江教育出版社。

刑福义 2001. ““ $p$, 但是 q” 及相关句式」, 「汉语复句研究」290-308 页。商务印书馆。

张谊生 2000. 现代汉语连词」, 「现代汉语虚词」140-194 页。华东师范大学出版社。

- 2004a. ““副十是” 的历时演化和共时变异」, 「现代汉语副词探索」385-416页。学 林出版社。

- 2004b. 「“就是” 的衔接、情态功能及其虚化历程」，「现代汉语副词探索」417-449 页。学林出版社。 